e-ISSN : 2598-5159

p-ISSN : 2598-0742

DOI : https://doi.org/10.31539/alignment.v2i1.613

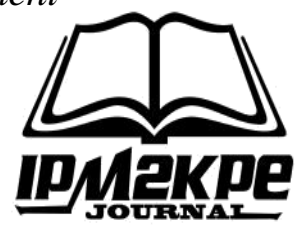

\title{
EVALUASI KINERJA PROGRAM STUDI DI PENDIDIKAN TINGGI PERSPECTIVE BALANCE SCORE
}

\author{
Adisel \\ Institut Agama Islam Negeri Bengkulu \\ adisel@iainbengkulu.ac.id
}

\begin{abstract}
ABSTRAK
Tujuan dari penelitian ini adalah untuk mengetahui bagaimana evaluasi kinerja program studi di pendidikan tinggi perspective balance score. Metode yang digunakan dalam penelitian ini adalah mix methods antara metode penelitian kuantitatif dan kualitatif. Evaluasi program dan jaminan kualitas telah menjadi elemen penting dalam upaya peningkatan berkelanjutan dalam program rehabilitasi publik dan organisasi rehabilitasi berbasis masyarakat. pendidikan tinggi, (2) apakah ada peningkatan kinerja pendidikan tinggi, program studi dilihat dari perspektif balanced scorecard. Artikel ini adalah model evaluasi ulasan program dalam layanan pendidikan tinggi. Selain itu, artikel menunjukkan analisis jurnal terkait lainnya. Ini dilanjutkan (1) hasil penilaian proses akreditasi kinerja pendidikan tinggi dengan 4 perspektif yang seimbang yang terlihat (a) berdasarkan perspektif scorecard keuangan dalam posisi yang cukup baik (b) perspektif pelanggan pendidikan tinggi berada dalam kategori baik (c) di proses inovasi, dapat dilihat sebagai kebutuhan pelanggan yang muncul, universitas adalah produk atau layanan untuk memenuhi kebutuhan tersebut. (d) perspektif pembelajaran dan pertumbuhan yang ada berjalan cukup baik. Simpulan, Hasil akreditasi yang dilakukan secara umum dapat mencerminkan kelayakan dan akuntabilitas instansi dalam pengelolaan pendidikan tinggi.
\end{abstract}

Kata Kunci: Evaluasi Kinerja, Balanced Scorecard

\section{ABSTRACT}

The purpose of this study is to find out how to evaluate the performance of study programs in higher education perspective balance score. The method used in this study is a mix of methods between quantitative and qualitative research methods. Program evaluation and quality assurance have become important elements in the efforts to continuously improve public rehabilitation programs and communitybased rehabilitation organizations. higher education, (2) whether there is an increase in higher education performance, the study program is seen from the perspective of the balanced scorecard. This article is an evaluation model of program reviews in higher education services. In addition, the article shows the analysis of other related journals. This continues (1) the results of the higher education performance accreditation assessment process with 4 balanced perspectives that are visible (a) based on the perspective of the financial scorecard in a fairly good position (b) the perspective of the higher education customer is in the good category (c) in the innovation process, can seen as an emerging customer need, a university is a product or service to meet those needs. (d) the existing learning and growth perspective is going quite well. In conclusion, 
the results of accreditation conducted in general can reflect the feasibility and accountability of agencies in the management of higher education.

\section{Keywords: Performance Evaluation, Balanced Scorecard}

\section{PENDAHULUAN}

Pesatnya perkembangan Pendidikan Tinggi di Indonesia berjalan seiringan dengan pertumbuhan ekonomi. Berdasarkan hal inilah pengukuran kinerja dalam pengelolaan program studi pendidikan tinggi dianggap sangat penting, dan mendorong direktorat jenderal pendidikan tinggi memasukkannya dalam format manajemen baru yang bertujuan untuk meningkatkan kualitas pendidikan secara berkelanjutan dengan membentuk Badan Akreditasi.

Berdasarkan Keputusan Menteri Pendidikan Nasional nomor 28 tahun 2005, badan yang ditunjuk untuk melakukan akreditasi program studi dan pendidikan tinggi adalah Badan Akreditasi Nasional Pendidikan Tinggi. Sebagai satu satunya badan yang ditunjuk untuk melaksanakan akreditasi Pendidikan Tinggi, BAN-PT diharapkan menjadi badan yang akuntable untuk melaksanakan proses akreditasi Pendidikan Tinggi. Untuk menjamin kualitas program studi pasca akreditas yang dilakukan oleh BAN-PT maka diperlukan suatu pengukuran kinerja yang modern. Pengukuran kinerja dalam prespektif yang strategis memerlukan penggabungan dari berbagai elemen area pengukuran.

Balance scorecard sebagai salah satu alat yang mengintegrasikan elemen keuangan dan non-keuangan strategis, dengan pengintegrasian pengukuran outcome dan driver kinerja outcome dalam kerangka hubungan sebab akibat Penggunaan balance scorecard sebagai alat ukur kinerja prodi pendidikan tinggi didasarkan pada indikator pengukurannya yang didasarkan pada perspektif keuangan, perspektif pelanggan, perspektif proses bisnis internal, dan perspektif pembelajaran dan pertumbuhan.

Berdasarkan hal tersebut artikel ini disusun untuk mengetahui, menganalisis dan mendeskripsikan (1) hasil akreditasi sudah mencerminkan kelayakan dan akuntabilitas dalam pengelolaan prodi pendidikan tinggi; (2) terdapat peningkatan kinerja prodi pendidikan tinggi pasca evaluasi BAN-PT dilihat dari perspektif balanced scorecard.

Ada beberapa definisi mengenai manajemen yang diberikan oleh para ahli. Robbins dan Coulter (1999) menyebutkan manajemen adalah proses pengkoordinasian dan pengintegrasian kegiatan-kegiatan kerja agar diselesaikan secara efektif dan efisien melalui orang lain. Menurut Siswanto (2001:1) Manajemen adalah proses perencanaan, pengorganisasian, kepemimpinan dan pengendalian upaya anggota organisasi dan penggunaan seluruh sumber daya organisasi lainnya demi tercapainya tujuan organisasi.

Manajemen menurut Amin Widjaya (2002) adalah "The art of getting things done trhough other people" (Seni menyelesaikan segala sesuatu melalui orang lain). Manajemen adalah proses perencanaan (planning), pengarahan 
(leading), dan pengendalian (controlling), kegiatan anggota organisasi lainnya untuk mencapai tujuan organisasi (Wijaya, 2002).

Selain itu Bush dalam Bush dan Coleman (2006) menyatakan bahwa "Manajemen pendidikan adalah suatu studi dan praktek yang dikaitkan atau diarahkan dalam operasional organisasi pendidikan". Organisasi pendidikan membutuhkan suatu bentuk pengaturan kegiatan. Pengaturan kegiatan tersebut mengarah pada suatu sistem yang sistematis. Pengaturan kegiatan yang sistematis itu akan dijadikan sebagai patokan dalam pelaksanaan kegiatan operasional yang terwujud dalam suatu manajemen pendidikan.

Berdasarkan pendapat di atas dapat disimpulkan bahwa manajemen pendidikan merupakan suatu bentuk kerjasama sekelompok manusia, baik studi dan praktek operasional penyelenggaraan pendidikan dalam upaya mewujudkan tujuan pendidikan secara efektif dan efisien.

Bahasan utama yang akan disajikan dalam manajemen pendidikan tinggi adalah mengenai proses dan aktivitas manajemen yang perlu dilakukan, dengan pokok bahasan mengenai manajemen strategis dan cara pengukuran keberhasilan kinerja manajemen. Kecuali beberapa dimensi makna atau fungsi yang meliputi hakekat dari universitas, makna korporasipun masih mempunyai sub-dimensi pengertian lagi. Korporasi universitas dapat dipandang pula sebagai suatu lembaga, suatu perusahaan, dan suatu agen atau perantara. Mengenai hal ini misalnya, Balderston menulis sebagai berikut (Indrajit dan Djokopranoto, 2004):

'Now the university has become a mixture of institution, enterprise, and agency. This is partly because it has assembled a large and confusing range of activities and operations, but partly also because the major parties at interest want to view it in different ways; the faculty and students, as an institution; the trustees and some administrators, as an enterprise; and the government sponsors, as an agency. Conflict of purpose, law, motivation, and style flow from these different views.... But I believe that important consequences flow from the voluntaristic and self-propelling character of the process of learning by individuals and group of scholars.

Kaplan and Norton, (1996) merumuskan tujuan dan ukuran operasional dalam empat perspektif yaitu perspektif: (1) finansial, (2).Pelanggan (customers), (3) Proses bisnis internal (internal business process), serta pembelajaran dan (4) Pertumbuhan (learning and growth).

Balanced scorecard menurut Averson, (2012) merupakan sistem manajemen strategis yang menerjemahkan visi, misi dan strategi suatu organisasi kedalam tujuan dan ukuran operasional. Bangunan Balanced Scorecard dimulai dari visi organisasi. Visi di sini adalah situasi masa depan organisasi yang diinginkan. Kemudian visi ini diuraikan dalam perspektif-perspektif pengukuran. Pada masing-masing perspektif tersebut ditetapkan tujuan-tujuan strategis yang lebih spesifik yang merupakan penjabaran dari visi organisasi. 
Menurut Mulyadi (2001), Balanced Scorecard memiliki keunggulan sebagai berikut: Komprehensif Balanced Scorecard memperluas perspektif yang harus diperhatikan dalam pengukuran kinerja. Selain perspektif keuangan, paling tidak ada 3 (tiga) perspektif lain yang juga harus mendapatkan perhatian yakni pelanggan, proses bisnis internal dan pembelajaran dan pertumbuhan.Koheren

Untuk menjamin keterpaduan di antara perspektif ini, maka ukuran-ukuran yang dikembangkan untuk masing-masing perspektif ini mengandung hubungan sebab akibat baik secara langsung maupun tidak langsung. Seimbang, Keseimbangan sasaran strategik yang dihasilkan oleh sitem perencanaan strategik perting untuk menghasilkan kinerja keuangan berjangka panjang. Terukur, Keterukuran sasaran-sasaran strategik di ketiga perspektif di balanced scorecard menjanjikan perwujudan berbagai sasaran strategic non-keuangan, sehingga kinerja keuangan dapat berlipatganda dan berjangka panjang.Menurut Al-Hosaini dan Saudah Sofian (2015) we have reviewed the at present, the use of the Balanced Scorecard (BSC) in order to identify the most suitable perspectives to consider in order to assess the performance of higher education institutions.

\section{METODE PENELITIAN}

Metode evaluasi perspektif balanced scorecard adalah mixed methods antara metode penelitian kuantitatif dan kualitatif. Hal tersebut sejalan dengan Kaplan yang dikutip oleh Neuman (1997) bahwa pada umumnya penelitian sosial menggunakan kombinasi analisis logika yang dikonstruksikan (kuantitatif) dan logika dalam praktek (kualitatif), walaupun proporsi dari masing-masing tipe logika tersebut bervariasi. Penelitian menggunakan desain gabungan (mixed methods) yang dilakukan secara bersamaan dengan tujuan untuk saling melengkapi gambaran hasil studi mengenai fenomena yang diteliti dan untuk memperkuat analisis penelitian.

Data yang digunakan dalam evaluasi ini berupa data primer dan data sekunder. Teknik pengumpulan data dilakukan dengan kuesioner, observasi, wawancara dan dokumentasi. Secara umum prosedur analisis data tersebut dapat digambarkan sebagai berikut

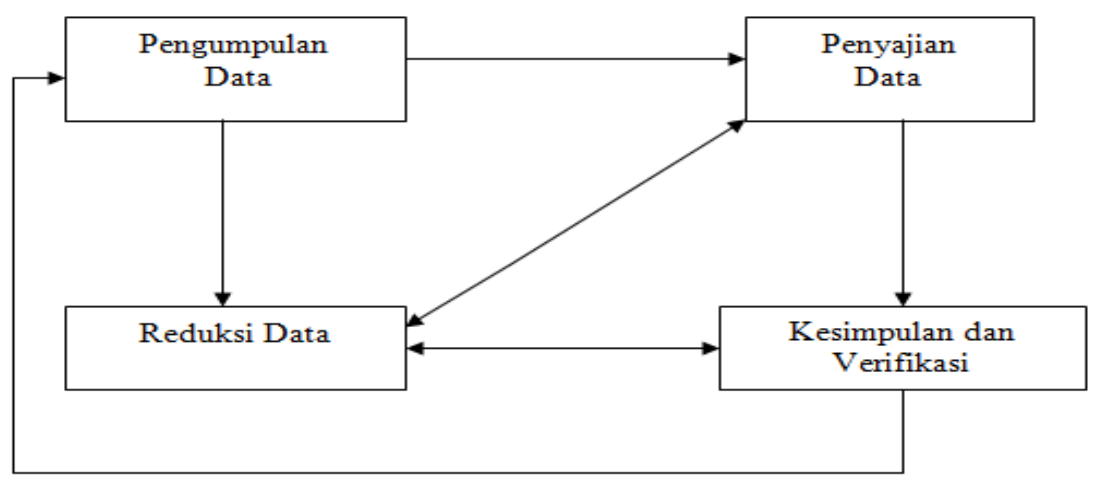




\section{HASIL DAN PEMBAHASAN}

\section{Perbandingan Hasil Akreditasi Pendidikan Tinggi dengan Standard Akreditasi}

Akreditasi pendidikan tinggi yang diterapkan dalam sistem pendidikan nasional dimaksudkan untuk menilai penyelenggaraan pendidikan tinggi. Penilaian itu diarahkan pada tujuan ganda, yaitu: menginformasikan kinerja pendidikan tinggi kepada masyarakat dan mengemukakan langkah pembinaan yang perlu ditempuh terutama oleh pendidikan tinggi dan pemerintah, serta partisipasi masyarakat.

Klasifikasi penilaian untuk semua kriteria tersebut ditentukan oleh 3 aspek, yaitu mutu (bobot 50\%), efisiensi (25\%), dan relevansi (25\%). Berdasarkan hasil penelitian diperoleh nilai akreditasi masing-masing pendidikan tinggi sebagai berikut:

Menurut Ashraf (2011) Ashraf Accreditation status of a college education is a reflection of the performance of higher education is concerned and describe the quality, efficiency, and relevance of the courses held. Accreditation should be done as an effort to maintain the quality of higher education. For those who have a higher education preparedness, accreditation is something awaited as a legitimate tool of education quality higher education is concerned.

\section{Dampak Hasil Akreditas terhadap Peningkatan Jumlah Mahasiswa}

Hasil akreditasi merupakan salah satu indikator yang mencerminkan pengelolaan pendidikan tinggi yang berkualitas. Hasil akreditasi yang baik dapat memicu peningkatan jumlah mahasiswa, akan tetapi ada konsekuensi lain dari status akreditasi yang disandangnya, pendidikan tinggi dituntut memberikan pelayanan yang baik dan layak bagi mahasiswanya, selain itu kualitas dan kuantitas tenaga pengajar yang dimiliki harus dikembangkan guna mendukung hasil akreditasi yang dilakukan.

Proses akreditasi memberikan dampak yang positif terhadap citra pendidikan tinggi, orientasi pendidikan tinggi bukan kepada peningkatan jumlah mahasiswa serta peningkatan kuota penerimaan saja, akan tetapi pendidikan tinggi lebih menekankan pada kualitas dan kuantitas mutu dari pendidikan tinggi tersebut. Disimpulkan bahwa secara umum terdapat peningkatan kinerja yang baik pada pendidikan tinggi setelah adanya akreditasi, akan tetapi perlu dikaji secara mendalam dan konfrehensif semua aspek yang menjadi bahan acuan bagi BAN dalam menilai sebuah pendidikan tinggi untuk mendapatkan status akreditasi yang menyatakan kredibilitas pendidikan tinggi yang bersangkutan.

\section{Evaluasi Kinerja Prodi Pendidikan Tinggi Pasca Akreditasi ditinjau dari perspektif Balanced Scorecard}

Tahapan dalam mengevaluasi kinerja suatu intitusi/pendidikan tinggi adalah membuat tujuan strategis organisasi yaitu menunjukkan bagaimana tindakan- 
tindakan yang harus dilakukan untuk melaksanakan strategi. Tujuan strategis lebih bersifat spesifikasi dari visi dan misi pendidikan tinggi. Visi dan strategi diterjemahkan kedalam empat perspektif yang kemudian oleh masing-masing perspektif visi dan strategi tersebut dinyatakan dalam bentuk sasaran yang ingin dicapai, ukuran dari sasaran, target yang diharapkan dimasa yang akan datang serta inisiatif sasaran strategis. Perspektif-perspektif dalam BSC terdiri atas perspektif keuangan, perspektif pelanggan, perspektif proses bisnis internal dan perspektif pembelajaran dan pertumbuhan.

Dalam lingkungan ini Balanced Scorecard sebagai kerangka konseptual untuk menerjemahkan misi dan tujuan menjadi satu set indikator kinerja yang didistribusikan di antara empat perspektif: Finansial (bagaimana pendidikan tinggi dimata pemberi dana). Pelanggan (bagaimana pelanggan memandang pendidikan tinggi). Proses bisnis internal (apakah pendidikan tinggi telah bekerja dengan produktif). Inovasi dan pembelajaran (apakah pendidikan tinggi telah menciptakan nilai bagi stakeholder).

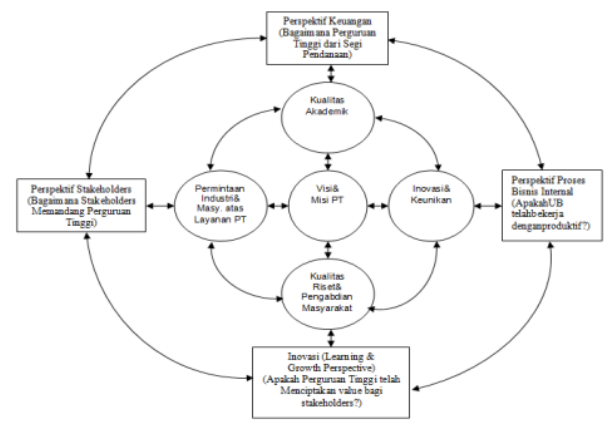

Pengukuran kinerja ini bertujuan untuk meningkatkan kemajuan organisasi ke arah yang lebih baik. Untuk dapat mengukur kinerja, maka harus ditetapkan ukuran-ukuran yang sesuai untuk setiap tujuan-tujuan strategis. Indikator ragaan kunci atau KPI (Key Performance Indicator) dikembangkan berdasarkan hasil analisis kondisi pendidikan tinggi yang terdiri dari dua kelompok yaitu KPI upaya (input) yang mencakup proses/program dan KPI luaran (output). Organisasi menggunakan fokus pengukuran scorecard untuk menghasilkan berbagai proses manajemen penting (Kaplan dan Norton, 1996), yaitu: Memperjelas dan menerjemahkan visi dan strategi. Mengomunikasikan dan mengaitkan berbagai tujuan dan ukuran strategis. Merencanakan, menetapkan sasaran, dan menyelaraskan berbagai inisiatif strategis. Meningkatkan umpan balik dan pembelajaran strategi.

Langkah-langkah selanjutnya adalah menyusun inisiatif strategis merupakan program-program yang harus dilakukan untuk memenuhi salah satu atau berbagai tujuan strategis. Sebelum menetapkan inisiatif, yang harus dilakukan adalah menentukan target. Target merupakan suatu tingkat kinerja yang diinginkan. Untuk setiap ukuran harus ditetapkan target yang ingin dicapai. Setelah target ditentukan maka selanjutnya ditetapkan program-program yang akan dilakukan untuk mencapai target tersebut. 
Menurut Jalaliyoon dan Taherdoost (2012) bahwa On the other hand, to achieve the final target of organization, performance evaluation that is an assessment model could help organizations to compare past plans and executions of strategies and sketch future strategies and set up performance targets of employees. Dengan penggunaan metode Balanced Scorecard pendidikan tinggi dapat mensinergikan sistem manajemen strategis dalam menterjemahkan misi dan strategi organisasi ke dalam sasaran-sasaran dan ukuran-ukuran ke dalam empat perspektif yaitu perspektif finansial, stakeholders, proses internal, serta learning \& growth dimana masing-masing perspektif dikembangkan lagi melalui tujuan, ukuran, sasaran, dan inisiatif. Adapun hasil uraian penelitian berdasarkan perspektif balanced scorecard adalah sebagai berikut:

\section{Perspektif Keuangan}

Pengukuran kinerja pendidikan tinggi berdasarkan perspektif keuangan dalam di ukur dari (a) Kinerja Operasi , (b) Posisi keuangan Pendidikan Tinggi dan (c) Nilai (saham) Pendidikan Tinggi.

Pendidikan tinggi swasta berdasarkan evaluasi cenderung aktif dalam menjalankan operasionalnya, sehingga penggunaan dana lebih diefisiensikan dan lebih ditingkatkan dalam hal investasi. Pengamatan dari pendidikan tinggi unggul di negara maju antara lain menunjukkan bahwa pendapatan dari uang kuliah maksimal hanyalah 23\%- 25\% dari seluruh pendapatan, baik di pendidikan tinggi negeri maupun swasta. Yang menarik adalah porsi pendapatan dari apa yang dinamakan dana abadi (endowment) yang ternyata sangat tinggi dari pendidikan tinggi swasta. Sedangkan untuk pendidikan tinggi negeri, dana abadi ini hampir tidak ada atau kalau ada hanya sedikit sekali, antara 1\%-5\% saja.

\section{Perspektif Pelanggan}

Hal tersebut dibuktikan dengan perolehan skor rata-rata yang menunjukkan bahwa perusahaan pengguna lulusan mengapresiasi dengan baik. Bekal kemampuan yang ditimba selama perkuliahan mampu diaplikasikan dengan baik dalam pekerjaannya. Alumni pendidikan tinggi secara umum menyatakan bahwa ilmu yang diperoleh selama belajar pada pendidikan tinggi bermanfaat pada perkembangan karirnya.

Hasil pengukuran yang baik menunjukkan bahwa pendidikan tinggi menghasilkan lulusan yang memiliki sikap mental dan etika profesi, pengetahuan, ketrampilan, kreatifitas, dan kepemimpinan unggul, dan berwawasan luas. Dengan kualitas mahasiswa/konsumen yang baik, pendidikan tinggi dapat berkembang mencapai visi dan misinya turut mencerdaskan kehidupan bangsa karena menjadi pendidikan tinggi pilihan masyarakat. 


\section{Perspektif Proses Bisnis Internal}

Dalam perspektif bisnis proses internal, mengidentifikasi upaya, prosesproses untuk mencapai tujuan yang telah dipaparkan dalam perspektif pelangggan dan keuangan. Proses Bisnis Internal didapat setelah penetapan tujuan perspektif pelanggan dan keuangan ditetapkan.

Pada proses inovasi, dapat diketahui kebutuhan pelanggan yang sedang berkembang atau yang masih tersembunyi, kemudian menciptakan produk atau jasa untuk memenuhi kebutuhan tersebut. Proses inovasi ini dangat penting dalam perspektif bisnis internal. Dalam proses ini terdiri dari dua komponen. Komponen yang pertama adalah proses untuk mengenali pasar dan pelanggan. Dalam pelaksanaan untuk memenuhi kebutuhan pelanggan tentunya lembaga harus memiliki informasi yang akurat dan lengkap tentang pasar dan pelanggan potensial yang dituju. Komponen yang kedua adalah proses perancangan dan pengembangan produk baru.

Dalam perspektif proses bisnis internal, kinerja pendidikan tinggi dilihat dari proses layanan purna jual kepada mahasiswa yang dilakukan oleh para karyawan dan dosen. Analisis proses bisnis internal menggunakan kuisioner yang diberikan kepada para karyawan maupun dosen serta mahasiswa untuk menilai kinerja proses bisnis internal tersebut. Proses tersebut mencerminkan aktivitas yang dilakukan pada mahasiswa mulai dari proses operasi, proses layanan purna jual sampai dengan pelayanan akademik maupun pelayanan proses belajar mengajar.

\section{Perspektif Pembelajaran dan Pertumbuhan}

Pada perspektif pertumbuhan dan pembelajaran harus diupayakan standar keahlian seluruh karyawannya baik dosen atau tenaga administrasi, investasi teknologi yang mendukung penyelenggaraan serta kelancaran proses kerja organisasi. Hal yang terpenting dalam BSC adalah adanya upaya pimpinan pendidikan tinggi untuk mencapai tujuan strategis secara keseluruhan dan didukung pemahaman serta integritas dari seluruh unit yang ada.

Perspektif ini sebenarnya berupaya bagaimana pendidikan tinggi memahami kondisi dirinya sehingga membuat suatu rencana/program jangka panjang dalam rangka perbaikan berkelanjutan (continous improvement). Keterlibatan berbagai pihak, termasuk staf akademik akan menciptakan institutional commitment guna menumbuhkan kesadaran diri (untuk tumbuh dan berkembang).

\section{Keterkaitan empat perspektif Balanced Scorecard pada Pendidikan Tinggi}

Dari uraian diatas menunjukkan bahwa penilaian kinerja Pendidikan Tinggi dengan menggunakan Balanced Scorecard dapat mengukur kinerja pendidikan tinggi dengan lebih komprehensif, sehingga manajemen dapat meningkatkan kinerjanya dimasa yang akan datang. 
Berdasarkan perspektif keuangan dikatakan baik jika pendidikan tinggi berupaya secara efisien menekan biaya untuk mengurangi pengeluaran dan hal ini juga diikuti dengan pencapaian pendapatan yang baik walaupun masih jauh dari yang ditargetkan. Namun tidak semua komponen biaya dilakukan secara efektif. Walaupun perubahan biaya mengalami penurunan kearah yang lebih baik namun besarnya angka pertumbuhan pendapatan masih jauh lebih kecil daripada jumlah perubahan biaya. Maka, diharapkan bagi pihak pendidikan tinggi untuk lebih meningkatkan pendapatannya sehingga dapat mencapai yang ditargetkan.

Dari perspektif pelanggan dikatakan baik jika pendidikan tinggi mampu mempertahankan jumlah pelanggan yang masuk setiap tahunnya dan juga mampu untuk meningkatkan jumlah pelanggan meskipun relatif kecil. Peningkatan kualitas pelayanan pun terus dilakukan termasuk dari segi SDM dan sarana prasarana. Diharapkan dengan adanya usaha-usaha tersebut akan meningkatkan jumlah pelanggan di tahun berikutnya sehingga akan meningkatkan pendapatan pendidikan tinggi tanpa mengurangi kualitas pelayanan dan kualitas pendidikan yang diberikan.

Dari perspektif proses bisnis internal dikatakan baik, jika pendidikan tinggi mampu meningkatkan proses layanan purna jual dan proses operasi, meskipun pada proses inovasi dengan menambah dan mengembangkan layanan jasa yang diberikan belum dapat dikembangkan. Diharapkan kedepannya pada perspektif ini dapat digali dikembangkan dari berbagai aspek, serta inovasi yang dilakukan terus menuju kearah yang lebih baik, sehingga dapat berkompetisi dalam persaingan pada kualitas pendidikan serta sarana prasarana yang baik. Menurut penelitian Griggs, Blackburn, Smith (2012) We argue that we cannot truly assess accountability and comparability without engaging a range of stakeholders, not only in soliciting their views on the outcome of the learning but also in the design and implementation of evaluation processes.

Dari perspektif pertumbuhan dan pembelajaran dikatakan baik jika kinerja pendidikan tinggi dianggap baik. Hal ini dikarenakan pendidikan tinggi dapat mengembangkan SDM nya baik dari segi kompetensi maupun pelatihan ketrampilan meskipun belum mengikut sertakan karyawan seluruhnya dalam berbagai pelatihan. Walaupun begitu, pihak pendidikan tinggi masih mampu untuk mempertahankan jumlah karyawannya dengan menyediakan fasilitas yang mendukung dalam proses pembalajaran maupun kegiatan lainnya. Selain itu tingkat pemotivasian karyawan yang tinggi mampu meningkatkan produktivitas karyawan. pendidikan tinggi juga mampu memberikan iklim kerja yang baik dan kondusif sehingga hal ini berdampak pada kepuasan karyawan terhadap institusi.

\section{SIMPULAN}

Berdasarkan hasil pembahasan tersebut dapat ditarik beberapa kesimpulan sebagai berikut: Hasil akreditasi yang dilakukan secara umum dapat mencerminkan kelayakan dan akuntabilitas instansi dalam pengelolaan pendidikan 
tinggi. Hal tersebut dapat dilihat dari jumlah lulusan serta mahasiswa baru yang rendah serta komposisi dosen dan mahasiswa yang belum seimbang,. Sehingga kelayakan dan akuntabilitas pengelolaan pendidikan tinggi masih harus disempurnakan.

\section{DAFTAR PUSTAKA}

Al-Hosaini, H., \& Sofian, S. (2015). A Review of Balanced Scorecard Framework in Higher Education Institution (HEIs). International Review of Management and Marketing, 5(1), 26-3

Ashraf, S. (2011). Measuring the Learning Organization's Construct in Pakistan: A Case of Public Sector Educational Institutes. European Journal of Social Sciences, 18(4)

Coulter, M., \& Stephen, R. P. (1999). Management. Sixth Edition. Jakarta: PT. Prehallindo

Griggs, B. S. (2012). Journal The Educational Scorecard: The Start of our Journey

Hikmat, A. (2009). Manajeman Pendidikan. Bandung: Pustaka Setia

Jalaliyoon, J., \& Taherdoost, T. (2012). Journal; Performance evaluation of higher education; a necessity

Kaplan, R. S., \& Norton, D. P. (1996). Balanced Scorecard. Jakarta: Erlangga

Mulyadi, M. (2001). Balanced Scorecard: Alat Manajemen Kontemporer untuk Pelipatganda Kinerja Keuangan Perusahaan. Jakarta: Salemba Empat

Neuman, W. L. (1997). Social Research Methods: Qualitative and Quantitative Approaches in Social Works. New York: Columbia University

Paul, A. (2012). "A Balanced Scorecard for City \& County Services", http: Ilwww.balanced scorecard.org

Richardus, E. I., \& Richardus, D. (2004). Manajemen Pendidikan Tinggi Modern, Jakarta

Siswanto, S. (2006). Pengantar Menajemen. Jakarta: Penerbit Bumi Aksara

Taherdoost, T. (2011). Journal Importance of higher education performance evaluation, balance scorecard

Tony, B \&., Marianne, C. (2006). Manajemen Strategis Kepemimpinan Pendidikan (terj.) oleh. Fahrurrozi. Yogyakarta: IRCiSoD

Weerasooriya, W. (2013). Journal Performance Evaluation using the Balanced Scorecard: The case of Sri Lankan Universities

Widjaya, A. (2002). Tunggal,Manajemen. Jakarta: Penerbit Rineka Cipta 